Original article

\title{
BROILER CHICKEN PERFORMANCE IN RESPONSE TO VARIOUS LEVELS OF RAW AND AUTOCLAVED RICE BRAN
}

\author{
E. EIZADI, F. SHARIATMADARI, M. A. KARIMI TORSHIZI \\ $\&$ H. R. HEMATI MATIN \\ Department of Animal Science, Faculty of Agriculture, Tarbiat Modares \\ University, Tehran, Iran
}

\section{Summary}

Eizadi, E., F. Shariatmadari, M. A. Karimi Torshizi \& H. R. Hemati Matin, 2015. Broiler chicken performance in response to various levels of raw and autoclaved rice bran. Bulg. $J$. Vet. Med., 18, No 4, 348-360.

The inclusion of raw or autoclaved rice bran $(\mathrm{RB})$ into broiler chicken diets was evaluated. A total of 420 broiler chickens (Ross 308) were assigned to a basal diet (without RB) or diets containing 6, 12, and $18 \%$ raw or autoclaved RB with 3 replicates of 20 chickens. By polynomial orthogonal contrasts, a significant reduction in body weight gain and feed intake $(\mathrm{L}: \mathrm{P}=0.048)$, the weight of abdominal fat ( $\mathrm{L}: \mathrm{P}=0.048)$, ether extract digestibility $(\mathrm{L}: \mathrm{P}=0.025)$, villus height ( $\mathrm{L}: \mathrm{P}=0.046)$, and crypt depth ( $\mathrm{L}$ and $\mathrm{Q}: \mathrm{P}=0.043$ ) was achieved by increasing the inclusion levels of raw or autoclaved $\mathrm{RB}$ in the diets. On day 42, significant decreases were found in the weights and the ash contents of tibia ( $\mathrm{L}: \mathrm{P}=0.003$ ) with increasing the level of raw RB in the diets. Decreased serum cholesterol was obtained following the inclusion of increasing levels of raw $R B(Q: P=0.015)$ or autoclaved $R B$ ( $L$ and $Q: P=0.015$ ) in the diets. The inclusion of $\mathrm{RB}$ in the diets resulted in poorer nutrient digestibility and performance, although it had some modulation effects on blood lipid biochemistry. It is suggested that the inclusion of raw $\mathrm{RB}$ in the diets should be limited to $6 \%$, however, autoclaving allowed inclusion of RB up to $12 \%$ in the broiler diets.

Key words: abdominal organs, blood biochemistry, broiler performance, digestibility, rice bran, tibia

\section{INTRODUCTION}

The rice bran $(\mathrm{RB})$ has become popular as a part of poultry diets. It has great potential as a byproduct dietary ingredient because it is a good source of protein, energy, vitamins, and minerals (Saunders, 1990). It is used in broiler diets at a level up to $12 \%$ without substantial effects (Gallinger et al., 2004). The use of RB might be restricted by its anti-nutritional substances i.e. non-starch polysaccharides, python (Lue et al., 1991), trypsin inhibitor (Barber \& Benedito, 1978), and low availability of amino acids (Farrell, 1994). There are several potential methods of accomplishing stabilisation, which mostly are associated with some type of 
heating (Mujahid et al., 2005). The heat treatment could improve RB quality (Lue et al., 1991) which is especially effective in the presence of moisture (Ramezanzadeh, 1999), and its inclusion in diets resulted in a significant improvement in performance of broiler chickens (Kratzer \& Payne, 1977; Saunders, 1990). The autoclaving is a combination of heat and moisture for RB treatment (Kratzer \& Payne, 1977), but the information on the inclusion of autoclaved RB in broiler diets is scarce and contradictory. Therefore, the present study was carried out to determine the effect of different levels of raw RB or autoclaved $\mathrm{RB}$ on bone mineralisation, intestinal morphology, nutrient digestibility, and broiler chicken performance.

\section{MATERIALS AND METHODS}

The Animal Ethics Committee of the Tarbiat Modares University, Tehran, Iran has approved the experiment.

\section{Birds and husbandry}

A total of 420 unsexed broiler chickens (Ross 308) were allocated to seven diets with 3 replicates of 20 chickens in each at a completely randomised design. Broiler chickens were placed as 20 birds $/ 2 \mathrm{~m}^{2}$. All

Table 1. Composition of the diets for broiler chickens from 15 to 28 and from 29 to 42 days of age ( $\%$ as fed basis or as stated)

\begin{tabular}{|c|c|c|c|c|c|c|c|c|}
\hline & \multicolumn{4}{|c|}{15 to 28 days of age } & \multicolumn{4}{|c|}{29 to 42 days of age } \\
\hline & $\begin{array}{l}\text { con- } \\
\text { trol }\end{array}$ & $\begin{array}{l}6 \% \\
\mathrm{RB}\end{array}$ & $\begin{array}{l}12 \% \\
\mathrm{RB}\end{array}$ & $\begin{array}{l}18 \% \\
\mathrm{RB}\end{array}$ & $\begin{array}{l}\text { con- } \\
\text { trol }\end{array}$ & $\begin{array}{l}6 \% \\
\mathrm{RB}\end{array}$ & $\begin{array}{l}12 \% \\
\mathrm{RB}\end{array}$ & $\begin{array}{l}18 \% \\
\mathrm{RB}\end{array}$ \\
\hline \multicolumn{9}{|l|}{ Ingredients } \\
\hline Corn grain & 59.00 & 53.99 & 48.55 & 43.06 & 63.46 & 58.30 & 52.90 & 47.60 \\
\hline Soybean meal (440 g CP/kg) & 31.00 & 29.60 & 28.80 & 28.05 & 26.00 & 24.90 & 24.00 & 23.00 \\
\hline Fish meal & 3.19 & 3.70 & 3.75 & 3.78 & 3.52 & 3.79 & 3.93 & 4.11 \\
\hline Soybean oil & 3.32 & 3.40 & 3.61 & 3.85 & 3.75 & 3.87 & 4.07 & 4.24 \\
\hline Rice bran & 0.00 & 6.00 & 12.00 & 18.00 & 0.00 & 6.00 & 12.00 & 18.00 \\
\hline Dicalcium phosphate & 1.27 & 1.13 & 1.06 & 1.02 & 1.14 & 1.04 & 0.99 & 0.92 \\
\hline Oyster shells & 0.76 & 0.86 & 0.89 & 0.91 & 0.83 & 0.83 & 0.84 & 0.86 \\
\hline Common salt & 0.32 & 0.30 & 0.32 & 0.31 & 0.31 & 0.30 & 0.030 & 0.30 \\
\hline Premix $^{1}$ & 5.00 & 5.00 & 5.00 & 5.00 & 5.00 & 5.00 & 5.00 & 5.00 \\
\hline DL-methionine $(980 \mathrm{~g} / \mathrm{kg})$ & 0.25 & 0.24 & 0.24 & 0.24 & 0.21 & 0.21 & 0.21 & 0.21 \\
\hline L-lysine $\mathrm{HCl}$ & 0.10 & 0.08 & 0.08 & 0.08 & 0.07 & 0.06 & 0.06 & 0.06 \\
\hline Vitamin E & 0.20 & 0.20 & 0.20 & 0.20 & 0.20 & 0.20 & 0.20 & 0.20 \\
\hline Total & 100 & 100 & 100 & 100 & 100 & 100 & 100 & 100 \\
\hline \multicolumn{9}{|l|}{ Calculated } \\
\hline $\begin{array}{l}\text { Metabolisable energy } \\
\text { (kcal/kg DM) }\end{array}$ & 3,050 & 3,051 & 3,050 & 3,050 & 3,150 & 3,150 & 3,150 & 3,150 \\
\hline Crude protein & 20.34 & 20.34 & 20.34 & 20.34 & 18.71 & 18.70 & 18.71 & 18.70 \\
\hline Calcium & 0.87 & 0.87 & 0.87 & 0.87 & 0.84 & 0.83 & 0.83 & 0.83 \\
\hline Available phosphorus & 0.44 & 0.43 & 0.43 & 0.43 & 0.41 & 0.41 & 0.41 & 0.41 \\
\hline Methionine & 0.60 & 0.60 & 0.60 & 0.60 & 0.59 & 0.54 & 0.54 & 0.59 \\
\hline Lysine & 1.21 & 1.20 & 1.20 & 1.20 & 1.07 & 1.07 & 1.08 & 1.08 \\
\hline
\end{tabular}

${ }^{1}$ Mineral premix Mn, 64 g; Zn, 44 g; Fe, 100 g; Cu, 16 g; I, 0.64 g; Vitamin premix; B, 3.3 g; B , 0.72 g; $\mathrm{K}_{3}, 1.6 \mathrm{~g}$; Vitamin E; 14.4 g; Vitamin D, 7 g; Vitamin A, 7.7 g; Pantothenic acid, 12 g; Pyridoxine, $6.2, \mathrm{mg}, \mathrm{B}_{12}, 14.4 \mathrm{~g}$; Choline chloride, $440 \mathrm{mg}$ per $\mathrm{kg}$ of the diet. 
broiler chickens were fed similar starter diet from 1 to 14 days of age (metabolisable energy $2,950 \mathrm{kcal} / \mathrm{kg}$ and crude protein $21.45 \%$ ). Diets consisted of basal diet (without RB addition), basal diet plus raw $\mathrm{RB}$ or autoclaved $\mathrm{RB}$ at the levels of 6,12 , or $18 \%$ for grower (15 to 28 days) and finisher (29 to 42 days) periods. The diets were formulated based on NRC (1994) recommendations as isocaloric and isonitrogenous (Table 1) and were offered ad libitum. The light regimen was set as $23 \mathrm{~h}$ light and $1 \mathrm{~h}$ darkness and temperature was gradually reduced by $3^{\circ} \mathrm{C}$ from the initial $32{ }^{\circ} \mathrm{C}$ in each week. Feed intake (FI), body weight gain (BWG), and feed conversion ratio (FCR) were measured weekly. To autoclaving, the RB samples were placed in shallow trays and were heated in the autoclave at 15 p.s.i. pressure and $121^{\circ} \mathrm{C}$ (Kartzer \& Payne, 1977).

\section{Blood sampling and analyses}

Six birds (2/replicate) were randomly selected and blood samples were taken from the wing vein at 42 days of age. Serum samples were taken and blood cholesterol and triglycerides were measured by specific kits (Pars Azmoon, Tehran) and a spectrophotometer (UV) at $546 \mathrm{~nm}$ wavelength.

\section{Carcass traits}

At 42 days of age, six birds (2/replicate) were randomly selected, weighed, slaughtered and, immediately after dressing, the complete gastrointestinal tract (GIT) was removed. Liver, abdominal fat, gizzard, pancreas and the right tibias were removed. These organs were cleaned, weighed and expressed relative to live body weights. The tibias were boiled for $2 \mathrm{~min}$, the surrounding meat and cartilaginous caps were removed. The weight of tibias was recorded and the lengths, large and small diameter of tibias were measured using a digital caliper $(0.01 \mathrm{~mm}$, Mitutoyo, Japan). The bones were dried in a forced-air oven for $24 \mathrm{~h}$ at $105{ }^{\circ} \mathrm{C}$ and their weights were recorded (Gallinger et al., 2004).

\section{Intestinal morphology}

Histological indices were measured according to Iji et al. (2001) method. Formalin-fixed tissue samples were dehydrated, cleared, and impregnated with paraffin. The processed tissues were then embedded in paraffin wax. Sections were cut $(5-6 \mu \mathrm{m})$ from the waxed tissue on the microtome. The slides were stained by haematoxylin and eosin. Histological indices were determined using a computeraided light microscopic image analyzer (Dino Capture 2.0). The villi height (VH) and crypt depth (CD) were measured, and the calculation was made for $\mathrm{VH}$ to $\mathrm{CD}$ ratio (villi index, VI). Five adjacent, vertically oriented villous-crypt units per section were used for analysis.

\section{Nutrient digestibility analysis}

A balance trial (39 to $42 \mathrm{~d}$ ) was made with titanium oxide $\left(\mathrm{TiO}_{2}, 2 \mathrm{~g} / \mathrm{kg}\right.$ diets $)$ as an indigestible marker for determination of nutrient digestibility. Six birds (2/replicate) were sacrificed after a three-day adaptation period at 42 days of age. The ileal digesta between the yolk sac and the terminal ileum $(2 \mathrm{~cm}$ above the ileocaecal junction) were gently removed and digesta samples were stored at $-20{ }^{\circ} \mathrm{C}$ until further processing. Titanium in feed and digesta was determined based on the method described by Short et al. (1996). Samples of oven-dried diets and digesta were ground to a fine texture. Diets and digesta were analysed for chemical composition. Dry matter, organic matter, crude protein, and ether extract of diets and digesta were determined by methods according to the 
Association of Official Analytical Chemists (AOAC, 1990). Gross energy was determined by an adiabatic bomb calorimeter standardised using benzoic acid (Parr Instruments, Moline, IL). Finally, nutrients digestibility were calculated using standard equations of digestibility.

\section{Statistical analysis}

The pen was used as the experimental unit and data were analysed as a completely randomised design by the GLM procedure of SAS (2004). Polynomial orthogonal contrasts were individually carried out for raw $\mathrm{RB}$ and autoclaved $\mathrm{RB}$ levels to investigate the linear and quadratic trends. In addition, independent comparisons were done for the groups fed RB vs. the control group. $\mathrm{P}$ values of $\leq 0.05$ were considered as significant.

\section{RESULTS}

Metabolisable energy, dry matter, crude protein, ether extract, crude fibre, $\mathrm{Ca}$, total phosphorus, and ash contents of tested RB was $2950 \mathrm{kcal} / \mathrm{kg}, 91.06,12.98$, $13.20,12.40,0.07,1.50$, and $12.10 \%$, respectively. Increasing the inclusion levels of raw or autoclaved $\mathrm{RB}$ in the diets caused a significant reduction in $\mathrm{BWG}$, FI, and a significant increase in FCR (L: $\mathrm{P}=0.048$ ) at both periods (Table 2). On day 42 , the tibia weight and tibia ash contents decreased ( $\mathrm{L}: \mathrm{P}=0.003$ ) by increasing the levels of raw $\mathrm{RB}$ in the diets (Table 3). No significant trends were observed in other parameters.

The effect of diets on the organs and abdominal fat weights of broiler chickens at day 42 is displayed in Table 4. Increased dietary levels of raw or autoclaved RB increased the weights of gizzard ( $\mathrm{L}$ and $\mathrm{Q}: \mathrm{P}=0.034)$ and pancreas (L: $\mathrm{P}=0.045)$ as well as decreased abdominal fat weights ( $\mathrm{L}: \mathrm{P}=0.048$ ). On the $42^{\text {nd }}$ day, significant decrease was obtained in serum cholesterol after inclusion of increasing levels of raw $\mathrm{RB}(\mathrm{Q}: \mathrm{P}=0.015)$ and autoclaved $\mathrm{RB}$ ( $\mathrm{L}$ and $\mathrm{Q}: \mathrm{P}=0.015$ ) in the diets (Table 5). No significant trend was observed in serum triglycerides.

Table 2. Effects of increasing levels of raw and autoclaved rice bran (RB) in broiler chicken diets on body weight gain $(\mathrm{BWG} / \mathrm{g})$, feed intake $(\mathrm{FI} / \mathrm{g})$, and feed conversion ratio (FCR) in grower and finisher phases (means \pm SEM)

\begin{tabular}{lcccccc}
\hline & \multicolumn{3}{c}{ Grower (days 15 to 28) } & \multicolumn{3}{c}{ Finisher (days 29 to 42) } \\
\hline Item & BWG & FI & FCR & BWG & FI & FCR \\
\hline Control diet & $987 \pm 3.2$ & $1675 \pm 3.8$ & $1.69 \pm 0.001$ & $1285 \pm 9.0$ & $2724 \pm 5.3$ & $1.93 \pm 0.001$ \\
6\% raw RB & $975 \pm 3.2$ & $1668 \pm 3.2$ & $1.70 \pm 0.008$ & $1254 \pm 3.0$ & $2704 \pm 5.5$ & $1.96 \pm 0.003$ \\
12\% raw RB & $906 \pm 3.6$ & $1616 \pm 1.7$ & $1.78 \pm 0.007$ & $1195 \pm 3.0$ & $2660 \pm 4.9$ & $2.03 \pm 0.004$ \\
18\% raw RB & $814 \pm 2.7$ & $1552 \pm 2.1$ & $1.90 \pm 0.007$ & $1073 \pm 4.2$ & $2600 \pm 1.7$ & $2.20 \pm 0.007$ \\
P value for trend & & & & & & \\
$\quad$ Linear & 0.037 & 0.021 & 0.021 & 0.017 & $<0.001$ & $<0.001$ \\
$\quad$ Quadratic & 0.225 & 0.110 & 0.019 & 0.148 & 0.051 & 0.001 \\
6\% autoclaved RB & $977 \pm 3.9$ & $1665 \pm 4.0$ & $1.70 \pm 0.003$ & $1257 \pm 5.7$ & $2706 \pm 2.3$ & $1.95 \pm 0.009$ \\
12\% autoclaved RB & $906 \pm 1.5$ & $1619 \pm 3.2$ & $1.78 \pm 0.003$ & $1200 \pm 3.8$ & $2664 \pm 3.8$ & $2.03 \pm 0.009$ \\
18\% autoclaved RB & $815 \pm 5.9$ & $1556 \pm 2.1$ & $1.9 \pm 0.011$ & $1079 \pm 3.4$ & $2596 \pm 7.5$ & $2.19 \pm 0.012$ \\
P value for trend & & & & & & \\
$\quad$ Linear & 0.048 & 0.017 & 0.016 & 0.026 & 0.001 & 0.111 \\
$\quad$ Quadratic & 0.129 & 0.319 & 0.078 & 0.689 & 0.223 & 0.122 \\
\hline
\end{tabular}


Broiler chicken performance in response to various levels of raw and autoclaved rice bran

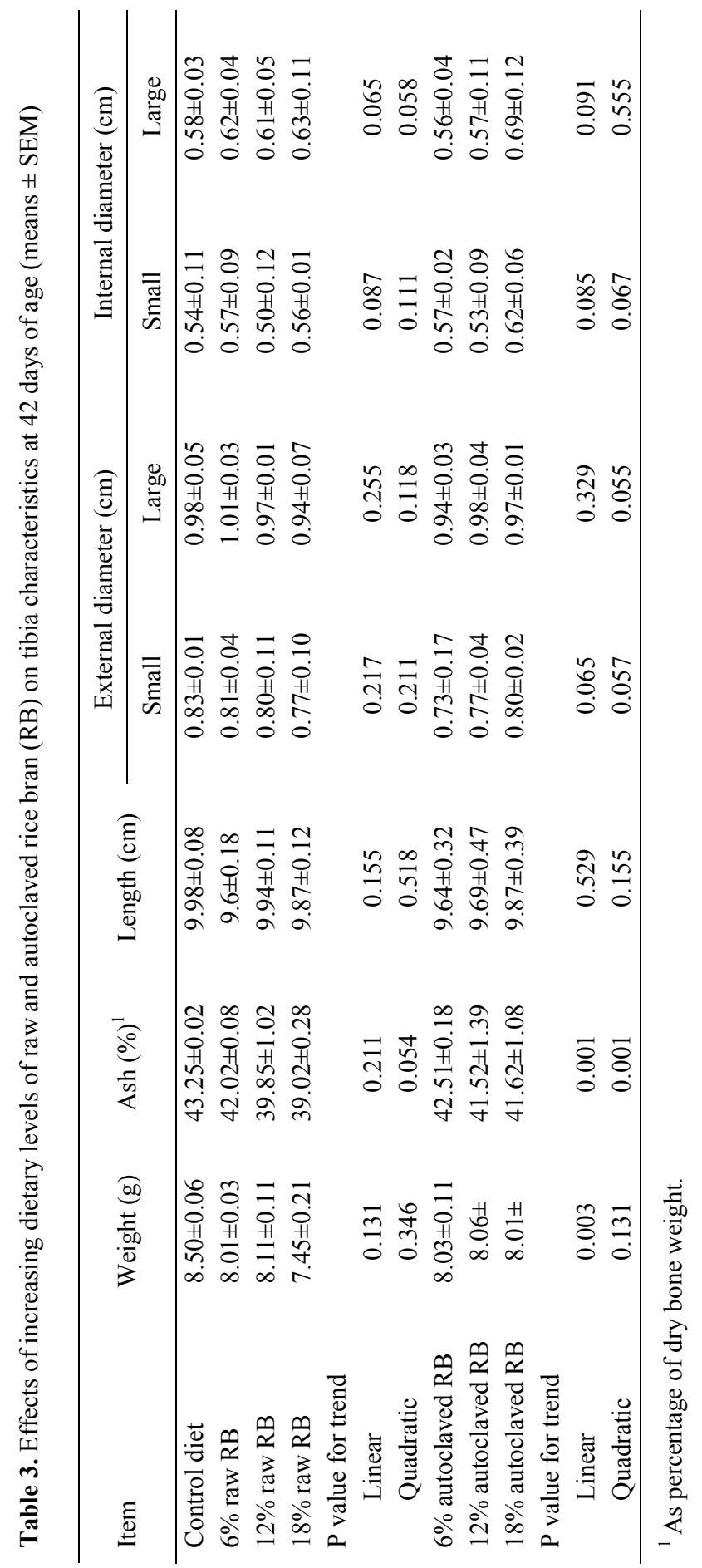


Table 4. Effects of increasing levels of raw and autoclaved rice bran (RB) in broiler chicken diets on the gizzard, pancreas, liver, and abdominal fat weights (\% of live body weight) at 42 days of age (means \pm SEM)

\begin{tabular}{lcccc} 
Item & Gizzard & Pancreas & Liver & Abdominal fat \\
\hline Control diet & $1.25 \pm 0.015$ & $0.23 \pm 0.004$ & $2.03 \pm 0.221$ & $2.16 \pm 0.286$ \\
6\% raw RB & $1.53 \pm 0.025$ & $0.24 \pm 0.047$ & $2.1 \pm 0.303$ & $1.96 \pm 0.0168$ \\
12\% raw RB & $1.56 \pm 0.68$ & $0.25 \pm 0.006$ & $1.9 \pm 0.187$ & $1.74 \pm 0.0150$ \\
18\% raw RB & $1.57 \pm 0.025$ & $0.27 \pm 0.004$ & $2.13 \pm 0.048$ & $1.62 \pm 0.019$ \\
P value for trend & & & & \\
$\quad$ Linear & 0.011 & 0.045 & 0.321 & 0.037 \\
$\quad$ Quadratic & 0.034 & 0.418 & 0.110 & 0.225 \\
6\% autoclaved RB & $1.53 \pm 0.066$ & $0.22 \pm 0.006$ & $2.22 \pm 0.064$ & $1.94 \pm 0.218$ \\
12\% autoclaved RB & $1.53 \pm 0.017$ & $0.23 \pm 0.005$ & $2.11 \pm 0.165$ & $1.82 \pm 0.127$ \\
$18 \%$ autoclaved RB & $1.64 \pm 0.856$ & $0.25 \pm 0.004$ & $2.27 \pm 0.026$ & $1.73 \pm 089$ \\
P value for trend & & & & \\
$\quad$ Linear & 0.031 & 0.029 & 0.211 & 0.048 \\
$\quad$ Quadratic & 0.021 & 0.165 & 0.312 & 0.129 \\
\hline
\end{tabular}

Table 5. Effects of increasing levels of raw and autoclaved rice bran (RB) in broiler chicken diets on serum cholesterol and triglycerides at 42 days of age (means \pm SEM)

\begin{tabular}{lcc}
\hline Item & Total cholesterol, mmol $/ \mathrm{L}$ & Triglycerides, $\mathrm{mmol} / \mathrm{L}$ \\
\hline Control diet & $3.03 \pm 0.081$ & $0.79 \pm 0.019$ \\
6\% raw RB & $2.99 \pm 0.034$ & $0.79 \pm 0.045$ \\
12\% raw RB & $2.88 \pm 0.014$ & $0.78 \pm 0.036$ \\
18\% raw RB & $2.79 \pm 0.033$ & $0.89 \pm 0.006$ \\
P value for trend & & \\
$\quad$ Linear & 0.618 & 0.321 \\
$\quad$ Quadratic & 0.015 & 0.110 \\
6\% autoclaved RB & $3.03 \pm 0.031$ & $0.80 \pm 0.059$ \\
12\% autoclaved RB & $2.87 \pm 0.091$ & $0.79 \pm 0.021$ \\
18\% autoclaved RB & $2.81 \pm 0.047$ & $0.78 \pm 0.037$ \\
P value for trend & & \\
$\quad$ Linear & 0.009 & 0.211 \\
$\quad$ Quadratic & 0.015 & 0.312 \\
\hline
\end{tabular}

Table 6 shows the effect of the diets on ileal digestibility of nutrients in broiler chickens at day 42. Significant decreases was found in the digestibility of dry matter, metabolisable energy ( $\mathrm{L}$ and $\mathrm{Q}$ : $\mathrm{P}=0.046$ ), crude protein and ether extract (L: $\mathrm{P}=0.025)$ after increasing the levels of raw or autoclaved RB in the diets. Table 7 illustrates the effect of RB inclusion in the diets on intestinal morphology of broiler chickens. Increased levels of raw or auto- claved $\mathrm{RB}$ reduced significantly the $\mathrm{VH}$ (L: $\mathrm{P}=0.046$ ) and the $\mathrm{CD}(\mathrm{L}$ and $\mathrm{Q}$ : $\mathrm{P}=0.043)$. In addition, the broiler chickens fed the diets with increasing levels of autoclaved RB had lower VI ( $\mathrm{L}$ and $\mathrm{Q}$ : $\mathrm{P}=0.024$ ).

On day 42, the length of jejunum, ileum, caecum, and the relative length of caecum increased paralelly to dietary levels of raw or autoclaved RB (Table 8, $\mathrm{L}$ and $\mathrm{Q}: \mathrm{P}=0.043$ ). A significant increase 
Broiler chicken performance in response to various levels of raw and autoclaved rice bran

Table 6. Effects of increasing levels of raw and autoclaved rice bran (RB) in broiler chicken diets on the apparent ileal digestibility of nutrients (means \pm SEM)

\begin{tabular}{lccccc}
\hline Item & Dry matter & $\begin{array}{c}\text { Organic } \\
\text { matter }\end{array}$ & $\begin{array}{c}\text { Metabolisable } \\
\text { energy }\end{array}$ & $\begin{array}{c}\text { Crude pro- } \\
\text { tein }\end{array}$ & $\begin{array}{c}\text { Ether ex- } \\
\text { tract }\end{array}$ \\
\hline Control diet & $86.56 \pm 0.70$ & $74.88 \pm 0.57$ & $76.00 \pm 0.63$ & $75.89 \pm 0.48$ & $66.22 \pm 0.99$ \\
6\% raw RB & $84.73 \pm 0.55$ & $74.67 \pm 0.47$ & $75.20 \pm 1.22$ & $74.99 \pm 0.64$ & $65.74 \pm 0.79$ \\
12\% raw RB & $82.86 \pm 1.26$ & $74.60 \pm 0.75$ & $74.61 \pm 0.23$ & $73.16 \pm 0.19$ & $63.61 \pm 0.99$ \\
18\% raw RB & $76.70 \pm 1.57$ & $73.31 \pm 0.91$ & $73.79 \pm 1.04$ & $71.00 \pm 0.80$ & $61.78 \pm 0.62$ \\
P value for trend & & & & & \\
$\quad$ Linear & 0.003 & 0.113 & 0.009 & 0.011 & 0.001 \\
$\quad$ Quadratic & 0.089 & 0.618 & 0.139 & $<0.001$ & 0.001 \\
6\% autoclaved RB & $86.13 \pm 0.86$ & $74.75 \pm 0.50$ & $75.84 \pm 0.49$ & $75.28 \pm 0.84$ & $65.46 \pm 2.09$ \\
12\% autoclaved RB & $83.70 \pm 1.40$ & $74.74 \pm 0.67$ & $75.83 \pm 1.26$ & $73.42 \pm 0.87$ & $63.79 \pm 1.26$ \\
18\% autoclaved RB & $77.13 \pm 1.12$ & $73.78 \pm .48$ & $75.83 \pm 1.29$ & $71.79 \pm 0.82$ & $61.45 \pm 1.65$ \\
P value for trend & & & & & \\
$\quad$ Linear & 0.046 & 0.678 & 0.041 & 0.025 & 0.024 \\
$\quad$ Quadratic & 0.099 & 0.512 & 0.370 & 0.772 & 0.273 \\
\hline
\end{tabular}

Table 7. Effects of increasing levels of raw and autoclaved rice bran (RB) in broiler chicken diets on jejunal villi height, crypt depth, and villi index at 42 days of age (means \pm SEM)

\begin{tabular}{lccc}
\hline Item & Villi height $(\mathrm{mm})$ & Crypt depth $(\mathrm{mm})$ & Villi height/crypt depth \\
\hline Control diet & $0.286 \pm 0.003$ & $0.263 \pm 0.006$ & $0.208 \pm 0.061$ \\
6\% raw RB & $0.288 \pm 0.025$ & $0.267 \pm 0.001$ & $0.214 \pm 0.039$ \\
12\% raw RB & $0.291 \pm 0.028$ & $0.253 \pm 0.015$ & $0.210 \pm 0.310$ \\
18\% raw RB & $0.286 \pm 0.029$ & $0.270 \pm .006$ & $0.214 \pm 0.009$ \\
P value for trend & & & \\
$\quad$ Linear & 0.046 & 0.043 & 0.221 \\
$\quad$ Quadratic & 0.219 & 0.019 & 0.422 \\
6\% autoclaved RB & $0.295 \pm 0.056$ & $0.274 \pm 0.028$ & $0.209 \pm 0.338$ \\
12\% autoclaved RB & $0.288 \pm 0.055$ & $0.256 \pm 0.012$ & $0.211 \pm 0.128$ \\
18\% autoclaved RB & $0.287 \pm 0.009$ & $0.269 \pm 0.007$ & $0.216 \pm 0.067$ \\
P value for trend & & & \\
$\quad$ Linear & 0.025 & 0.038 & 0.001 \\
$\quad$ Quadratic & 0.553 & 0.019 & 0.024 \\
\hline
\end{tabular}

was observed in the weight of duodenum (Q: $\mathrm{P}=0.016)$ and caecum ( $\mathrm{L}$ and $\mathrm{Q}$ : $\mathrm{P}=0.028$ ) (Table 9). Moreover, the relative weights of ileum ( $\mathrm{L}: \mathrm{P}=0.045)$ and caecum ( $\mathrm{L}$ and $\mathrm{Q}: \mathrm{P}=0.042$ ) were higher with the increasing levels of raw or autoclaved RB in diets, without significant trends in other parameters.

\section{DISCUSSION}

The results for the performance in the present study were in agreement with the findings of Mujahid et al. (2005), who reported that increasing the levels of $\mathrm{RB}$ in broiler chicken diets caused significant decreases in BWG and FI. There is a relationship between the rate of feed passage 


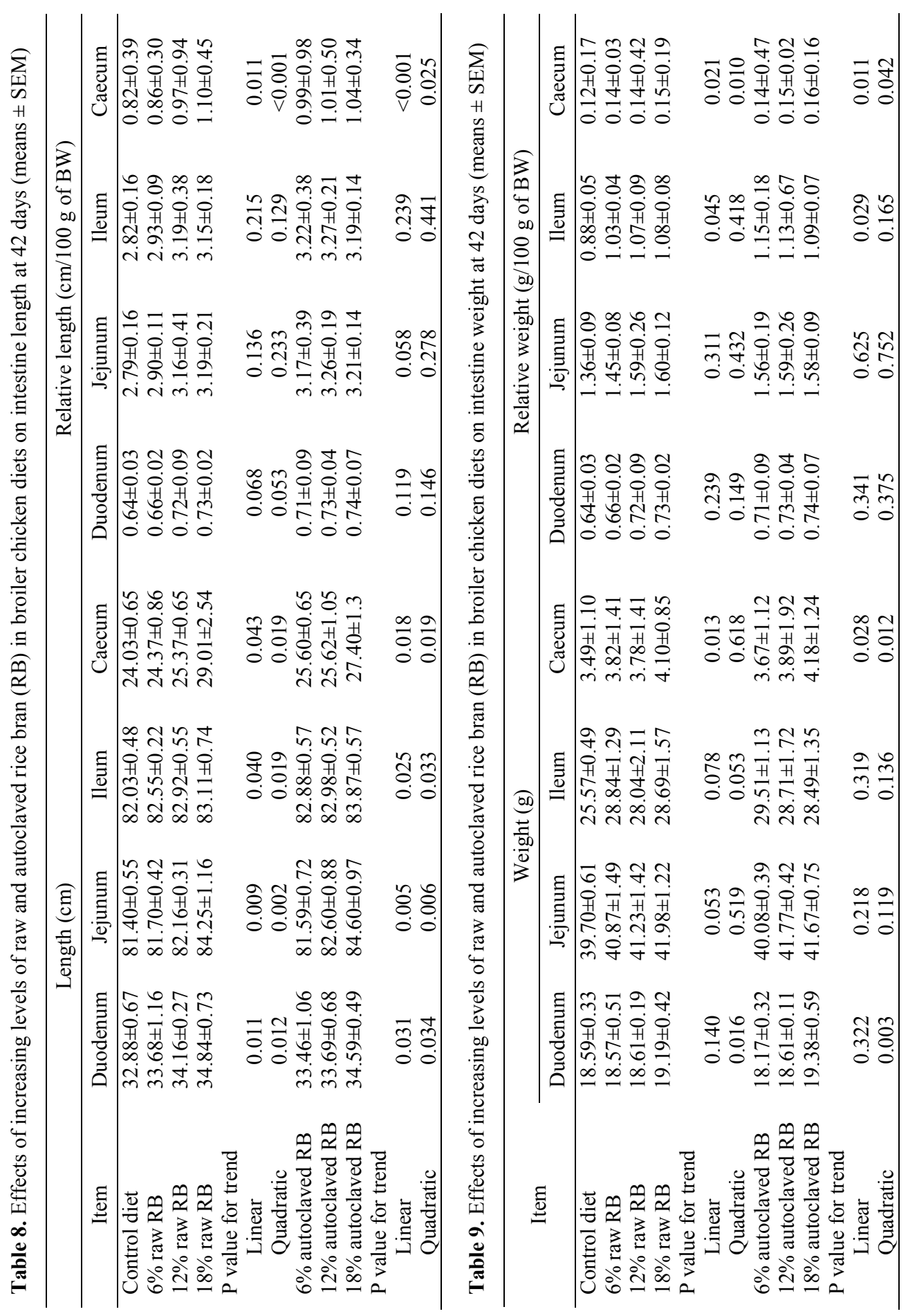


through the intestine and FI in young chickens (Almirall \& Garcia, 1994). The level of dietary fibre increases with inclusion of RB in diets (Sharma et al., 2004), which led to FI decreases (Van der Klis et al., 1993; Langhout et al., 1999). In addition, the viscosity of small intestinal digesta increases after inclusion of dietary fibre (Van der Klis et al., 1993) and thereby decreases utilisation of feed. This phenomenon was supported by the nutrient digestibility reduction measured in the present study. Lower BWG of broiler chickens on these diets was accompanied by lower FI. The use of autoclaved RB rather than raw $\mathrm{RB}$ resulted in relatively better BWG and FCR (Kratzer \& Pyne, 1977; Masood et al., 1995) which is in agreement with the results of the current study. The initial quality of RB is a determining factor on RB effects after autoclaving and broiler growth parameters in response to consumption of autoclaved $\mathrm{RB}$ in the diets.

Similar to the results of the current study, it is reported that tibia weight and ash contents of broilers are reduced by increasing the level of RB in diets which is attributed to the phytic acid and fibre content of RB (Adrizal et al., 1996; Galinger et al., 2004). The content of phytic acid and its derivatives is 5 to $7 \%$ in polished rice (Nelson et al., 1968). Also, about $90 \%$ of phosphorus in RB is as phytate (McCall et al., 1953). Phytate form some complexes with protein, vitamin, and minerals, which decrease the bioavailability of nutrients in poultry diets (Zyla et al., 1989), and lead to reduction in the $\mathrm{Fe}, \mathrm{Ca}$, and $\mathrm{Zn}$ accumulation of tibia (Khalique et al., 2003). Therefore, the broiler chickens fed the diets containing raw $\mathrm{RB}$ might have poorer mineralisation parameters. The autoclaved RB contains by $80 \%$ more available phosphorus than raw RB (Tangendjaja et al., 2006). Thus, autoclaving of RB could improve bone formation and mineralisation related parameters.

The weight and size of GIT organs development after consumption of $\mathrm{RB}$ was attributed to its arabinoxylan content (Shibuya \& Twasaki, 1985). The use of RB in broiler diets increases pancreatic weights because of the trypsin inhibitor in $\mathrm{RB}$ (Shibuya et al., 1985; Eshwaraiah et al., 1988). The trypsin inhibitor is extremely sensitive to heat and is completely destroyed by autoclaving (Kratzer \& Payne, 1977). Inclusion of RB (autoclaved for 15 min) in broiler diets improved growth rate with normal pancreatic weight. These results are consistent with the findings of the present study. El-Ghamry et al. (2005) reported that pancreatic and gizzard weights increased with $\mathrm{RB}$ increasing level in the diets. Increasing percentage of gizzard could be explained by increase in crude fibre content of RB which induced gizzard enlargement and in turn increased gizzard weight. In addition, broilers fed diets with high amounts of dietary fibre had lower abdominal fat (Shahin \& Abdelazim, 2005). In the presence of dietary fibre, the secretion of bile acids and hepatic-intestinal circulation was reduced (Mathlouthi et al., 2002) which restricted lipids emulsification. These events result in decreased lipids absorption and lead to lower abdominal fat contents (Shahin \& Abdelazim, 2005). Oladunjoye \& Ojebiyi (2010) reported that the high level of incorporation of $\mathrm{RB}$ in the diets led to a reduction in abdominal fat.

The reduction of cholesterol by increasing the levels of $\mathrm{RB}$ in the diets could relate to the high content of fatty acids in RB, which increases insoluble complexes and soap compounds and leads to lower cholesterol absorption. In line 
with the results of the present study, the cholesterol lowering properties of $\mathrm{RB}$ were approved by other researchers (ElGhamry et al., 2005).

The higher levels of crude fibre in diets containing RB (levels $>6 \%$ ) may be an important factor for explaining the reductions in nutrient digestibility in the current study. This is in agreement with other studies (Mujahid et al., 2005). The processing of RB by autoclaving resulted in some improvement in digestibility parameters. Heating RB in the presence of moisture (similar to autoclaving) was reported to be much more effective in achieving permanent improvements (Kratzer et al., 1977; Barber et al., 1978; Ramezanzadeh et al., 1999). The autoclaving of RB inactivates the lipases, trypsin inhibitors, and denaturates the antinutritional factors which improve the nutrients digestibility as reported by others (Saunders, 1990; Ramezanzadeh et al., 1999). Therefore, the autoclaving of RB increases digestibility of nutrients when included in diets as compared to raw RB.

The $\mathrm{VH}$ reduction in the presence of RB (especially $18 \%$ raw RB) could be due to its anti-nutritional effects rather than viscosity (Iji et al., 2001) and RB physical presence which leads to villi attrition. The attrition effects of fibre components shown in other studies (Leterme et al., 1998; Montagne et al., 2003) might lead to a waste of nutrients and endogenous cell losses in the lumen. Autoclaving omits some destructive effects of RB on villi characteristics. Inclusion of $18 \%$ raw $\mathrm{RB}$ in diets increased jejunum $\mathrm{CD}$. The viscose material in broiler diets results in deeper crypts at day 14 (Iji et al., 2001). Actually, the crypt is regarded as the villus factory and a large crypt indicates fast tissue turnover and a high demand for new tissue (Xu et al., 2003). Therefore, in- creased CD suggests a high potential for cell proliferation (Iji et al., 2001). As a result, deeper crypt obtained by treatments is due to unusual demand for cell proliferation and new tissue. These events were not observed with autoclaving of RB which could suggest that autoclaving moderates $\mathrm{RB}$ properties. The VI is a useful criterion for estimating the digestive capacity of the small intestine (Mateos et al., 2012). The raw or autoclaved RB at a level of $18 \%$ in diets led to the worst VI. This indicates that RB reduced digestive capacity of small intestine by VI reduction.

Saki (2005) noted that the diets containing fibre products (wheat and barley) increased the length of intestinal segments in broiler chickens, an adaptation to increase the exposure of the nutrients to digestive enzymes. The higher dietary RB levels increase dietary fibre contents. It is likely that increases in the jejunum, ileum, and caecum lengths are related to the contribution of RB to the physical enlargement of the intestine or RB with high water holding capacity or swelling capacity increases the retention time of feed in intestine and induces enlargement of intestinal segments (Ritz et al., 1995). Moreover, it is shown that older broilers adapt to diets containing fibre by developing the caeca (Jorgensen et al., 1996). Although this hypothesis is not proved, it is shown elsewhere that short-chain fatty acid diffusion stimulates cell proliferation (Johnson \& Gee, 1986) and could lead to caecum elongation. Other plausible mechanisms include caecal digesta osmolality and water holding capacity (Johnson \& Gee, 1986).

As previously noted, broilers adapt to high levels of fibres in diets by enlarging the GIT (Jorgensen et al., 1996), consequently, their weights increase. This adaptation is a rapid attempt to increase the absorptive surface area of the GIT in re- 
sponse to the lower diffusion rates, and it occurs by increasing the digesta viscosity levels (Johnson \& Gee, 1986; Viveros et al., 1994; Smits \& Annison, 1996; Iji et al., 2001; Banfield et al., 2002; JiménezMoreno et al., 2009). The results of the current study are in agreement with other studies in broiler chickens (Gallinger et al., 2004) and layers (Samli et al., 2006).

\section{CONCLUSIONS}

The diets containing rice bran had significantly poorer growth parameters compared with the control diet. Increasing the levels of rice bran in broiler chicken diets reduced nutrients digestibility and tibial bone ash. Feed intake and body weight gain of broiler chickens decreased by diets containing raw rice bran in excess of $6 \%$. Autoclaving with improving nutritional value of rice bran has positive effects on nutrients digestibility and its inclusion in broiler diets could increase up to $12 \%$ levels without having any adverse effects on bone mineralisation and broiler chicken performance.

\section{REFERENCES}

Adrizal, P. P. \& L. S. Jerry, 1996. Utilization of defatted rice bran by broiler chickens. Poultry Science, 75, 1012-1017.

Almirall, M. \& E. Estive-Garcia, 1994. Rate of passage of barley diets with chromium oxide: Influence of age and poultry strain and effect of $\beta$-glucanase supplementation. Poultry Science, 73, 1433-1440.

AOAC, 1990. Official Methods of Analysis, $15^{\text {th }}$ edn, Association of Official Analytical Chemists, Washington, DC, USA.

Banfield, M. J., P. P. Kwakkel \& J. M. Forbrs, 2002. Effects of wheat structure and viscosity on coccidiosis in broiler chickens. Animal Feed Science and Technology, 98, $37-48$.
Barber, S., C. Benedito de Barber, M. J. Flores \& J. J. Montes, 1978. Toxic constituents of rice bran. I. Trypsin inhibitor activity of raw and heat-treated bran. Revista de Agroquimica y Tecnologia de Alimentos, 18, 80-88.

El-Ghamry, A. A., M. A. Al-Harthi \& Y. A. Attia, 2005. Possibility to improve rice polishing utilization in broiler diets by enzymes or dietary formulation based on digestible amino acids. Archiv für Geflugelkunde, 69, S, 49-53.

Eshwaraiah, C., V. Reddy \& P. V. Rao, 1988. Effect of autoclaving and solid substrate fermentation of raw, deoiled and parbioiled rice polishing in broiler. Indian Journal of Animal Science, 58, 377-381.

Farrell, D. J., 1994. Utilization of rice bran in diet for domestic fowl and ducklings. World's Poultry Science Journal, 50, 115131.

Gallinger, C. I., D. M. Suarez \& A. Irazusta, 2004. Effects of rice bran inclusion on performance and bone mineralization in broiler chicks. International Journal of Poultry Science, 13, 183-190.

Iji, P. A., A. A. Saki \& D. R. Tivey, 2001. Intestinal development and body growth of broiler chicks on diets supplemented with non-starch polysaccharides. Animal Feed Science and Technology, 89, 175-188.

Jiménez-Moreno, E., J. González-Alvarado, R. Lázaro \& G. Mateos, 2009. Effects of type of cereal, heat processing of the cereal, and fiber inclusion in the diet on gizzard $\mathrm{pH}$ and nutrient utilization in broilers at different ages. Poultry Science, 88, 1925-1933.

Johnson, I. T. \& J. M. Gee, 1986. Gastrointestinal adaptation in response to soluble nonavailable polysaccharides in the rat. British Journal of Nutrition, 55, 497-505.

Jorgensen, H., X. Q. Zhao. K. E. Knudsen \& B. O. Eggum, 1996. The influence of dietary fiber source and level on the development of the gastrointestinal tract, digestibility and energy metabolism in broiler chickens. British Journal of Nutrition, 75, 379-395. 
Khalique, A., K. P. Lone., T. N. Pasha \& A. D. Khan, 2003. Chemical composition andnutritional evaluation of variously treated defatted rice polishing for broiler feeding. Asian-Australian Journal of Animal Science, 16, 873-879.

Kratzer, F. H. \& C. G. Pyne, 1977. Effect of autoclaving, hot-water treating, parboiling and addition of ethoxyquin on the value of rice bran as a dietary ingredient for chickens. British Poultry Science, 18, 475-482.

Langhout, D. J., J. B. Schutte, P. VanLeeuwen, J. Wiebenga \& S. Tamminga, 1999. Effect of dietary high-and low-methylated citrus pectin on the activity of the ilealmicroflora and morphology of the small intestinal wall of broiler chicks. British Poultry Science, 40, 340-347.

Leterme, P., E. Froidmont, F. Rossi \& A. Thewis, 1998. The high water-holding capacity of pea inner fibers affects the ileal flow of endogenous amino acids in pigs. Journal of Agriculture and Food Chemistry, 46, 1927-1934.

Lue, B. S., S. Barber \& D. B. C. Benedito, 1991. Rice bran: Chemistry and technology. In: Rice Production and Utilization, vol. II, ed B. S. Luh, pp. 313-315.

Masood, A., J. A. Qureshi \& M. Y. Malik, 1995. Rice polishing (solvent extruded) as a source of energy in broiler ration. In: Proceedings of the National Symposium of Animal Nutritionists, C.V.S., Lahore, University of Agriculture, Faisalabad, Pakistan.

Mateos, G., E. Jiménez-Moreno, M. Serrano \& R. Lázaro, 2012. Poultry response to high levels of dietary fiber sources varying in physical and chemical characteristics1. The Journal of Applied Poultry Research, 21, 156-174.

Mathlouthi, N., S. Mallet, L. Saulnier, B. Quemener \& M. Larbier, 2002. Effects of xylanase and -glucanase addition on performance, nutrient digestibility, and physico-chemical conditions in the small intestine contents and caecal microflora of broiler chickens fed a wheat and barleybased diet. Animal Research, 51, 395-406.

McCall, E. R., J. F. Jurgens, C. F. Hoffpauir, W. A. Pons., Jr. Stark, Jr. Cucullu, D. C. Heinzelmans, V. O. Cirino \& M. D. Murray, 1953. Composition of rice: Influence of variety and environment on physical and chemical composition. Journal of Agriculture and Food Chemistry, 1, 988-993.

Montagne, L., J. R. Pluske \& D. J. Hampson, 2003. A review of interactions between dietary fibre and the intestinal mucosa, and their consequences on digestive health in young non-ruminant animals. Animal Feed Science and Technology, 108, 95-117.

Mujahid, A., I. Ulhaq, M. Asif \& A. H. Gillani, 2005. Effect of various processing techniques and different levels of ontioxidant on stability of rice bran during storage. Journal of Food Science and Agriculture, 85, 847-852.

Nelson, T. S., T. R. Shieh, R. J. Wodzinski \& J. H. Ware, 1968. The availability of phytate phosphorus in soybean meal before and after treatment with mold phytase. Poultry Science, 47, 1842-1848.

NRC, 1994. Nutrient Requirement of Poultry, $9^{\text {th }}$ ed. National Academy of Sciences, National Research Council, Washington DC.

Oladunjoye, I. O. \& O. O. Ojebiyi, 2010. Performance characteristics of broiler chicken (Gallus gallus) fed rice (Oriza sativa) bran with or without Roxazyme G2G. International Journal of Animal and Veterinary Advances, 2, 135-140.

Ramezanzadeh, F., R. Rao, M. Windhauser, W. Prinyawiwatkul \& W. Marshall, 1999. Preventation of oxidative rancidity in rice bran during sortage. Journal of Agriculture and Food Chemistry, 47, 2997-3000.

Ritz, C. W., R. M. Hulet, B. B. Self \& D. M. Denbow, 1995. Growth and intestinal morphology of male turkeya as influenced by dietary supplementation of amylase and xylanase. Poultry Science, 74, 1329-1334.

Saki, A. A., 2005. Effect of wheat and barley viscosity on broiler performance in 
Hamedan province. International Journal of Poultry Science, 4, 7-10.

Samli, H. E., N. Senkoylu, H. Akyurek \& A. Agma, 2006. Using rice bran in laying hen diets. Journal of Central European Agriculture, 7, 137-140.

SAS Institute., 2004. SAS/STAT 9.1 User's Guide Introduction. SAS Institute Inc., Cary, North Carolina.

Saunders, R. M., 1990. The properties of rice bran as a foodstuff. Cereal Foods World, 35, 632-636.

Shahin, K. A. \& F. Abdelazim, 2005. Effects of breed, sex and diet and their Interaction on carcass composition and tissue weight distribution of broiler chickens. Archives Animal Breeding, 48, 612-625.

Sharma, R. H., G. S. Chauhan \& K. Agrawal, 2004. Physico-chemical characteristics of rice bran processed by dry heating and extrusion cooking. International Journal of Food Properties, 7, 603 -614.

Shibuya, N. \& T. Iwasaki, 1985. Structural features of rice bran hemicellulose. Phytochemistry, 24, 285-289.

Short, F., P. Gorton, J. Wiseman \& K. Boorman, 1996. Determination of titanium dioxide added as an inert marker in chicken digestibility studies. Animal Feed Science and Technology, 59, 215-221.

Smits, C. H. \& G. Annison, 1996. Non-starch plant polysaccharides in broiler nutritiontowards a physiologically valid approach to their determination. World's Poultry Science Journal, 52, 203-222.

Tangendjaja, B., K. A. Buckle \& M. Wootton, 2006. Dephosphorylation of phytic acid in rice bran. Journal of Food Science, 46, 1021-1024.
Van der Klis, J. D., A. Van Voorst \& C. Van Cruyningen, 1993. Effect of a soluble polysaccharide (carboxymethyl cellulose) on the physico-chemical conditions in the gastrointestinal tract of broilers. British Poultry Science, 34, 971-983.

Viveros, A., A. Brenes, M. Pizarro \& M. Castano, 1994. Effect of enzyme supplementation of a diet based on barley, and autoclave treatment, on apparent digestibility, growth performance and gut morphology of broilers. Animal Feed Science and Technology, 48, 237-251.

Xu, Z. R., C. H. Hu, M. S. Xia, X. A. Zhan \& M. Q. Wang, 2003. Effects of dietary fructooligosaccharide on digestive enzyme activities, intestinal microflora and morphology of male broilers. Poultry Science, 82, 1030-1036.

Zyla, K., J. Koreleski \& M. Kujawski, 1989. Dephosphorylation of phytate compound by means of acid phosphatase from Aspergillus miger. Journal of the Science of Food and Agriculture, 49, 315-324.

Paper received 11.12.2014; accepted for publication 22.01.2015

\section{Correspondence:}

Farid Shariatmadari

Department of Animal Science,

Faculty of Agriculture,

Tarbiat Modares University,

Tehran, 14115-336, Iran, tel: +982148292372 ,

e-mail: shariatf@modares.ac.ir 